\title{
Replacement value of unpeeled cassava rootmeal (UCRM) for maize in weaner rabbit diets
}

\author{
S.O.Omoikhoje ${ }^{1}$,A.M. Bamgbose ${ }^{2}$ and M.B. Aruna ${ }^{1}$ \\ 'Animal Science Department, Ambrose Alli University, Ekpom, Nigeria \\ -Animal Nutrition Department, University of Agriculture Abeokuta, Nigeria.
}

\begin{abstract}
Twenty four mixed breed (New Zealand $x$ Chinchila) rabbits aged six weeks with average initial weight of $560 \mathrm{~g}$ were used to examine the effect of replacing maize with unpeeled cassava root meal (UCRM) on the performance, organoleptic properties and economy of rabbit production. The rabbits were divided into four groups and assigned to four treatment diets formulated with $0,10,20$ and $30 \%$ UCRM respectively. Average live weight and weight gain were significantly $(P<0.05)$ improved by the increasing levels of URCM, but feed intake, feed conversion ratio and protein efficiency ratio were not significantly $(P>0.05)$ affected. All the organoleptic properties were not affected significantly $(P>0.05)$ by the dietary treatments. However, the increasing levels of UCRM reduced the cost per $\mathrm{kg}$ feed, feed cost per $\mathrm{kg}$ weight gain and cost of production of rabbits to matured weight. Therefore, the utilization of unpeeled cassava root meal as replacement for maize up to $30 \%$ level is profitable and feasible in rabbit diets formulation.
\end{abstract}

Keywords: Unpeeled cassava root meal, performance, organoleptic properties, economy of production, rabbits.

\section{Introduction}

The rapid deterioration of the nutritive value of food consumed by the Nigeria populace occasioned by the inadequate consumption of animal protein has remained unabated. As a result of this, pre-school children, expectant and nursing mothers are highly vulnerable to protein malnutrition which culminates in deficiency diseases such as Kwashiorkor, beriberi, maramus, intellectual dwarfism amongst others. To curb these nutritional deficiencies therefore, adequate steps must be taken to increase the quantity and quality of protein in the diets of an average Nigerian. In view of this, Biobaku $e t$ al (2003) opined that the production of traditional meat sources such as rabbits with short generation interval should be encouraged by government and research institutes.
Rabbits are highly prolific, efficient converters of plant products and seeds, easy to care for and require little capital outlay. The meat is white, fine grained, low in fat and caloric value, richer in protein and some minerals and vitamins (Aduku and Olukosi, 1990). There is no religious inhibition on the consumption of the meat in most cultures (Biobaku, 1998). Meanwhile, rabbit production in Nigeria is gaining much popularity, but it is constrained by the high cost of conventional feedstuffs which producers cannot afford. The escalating cost of maize and its attendant high demand and seasonal scarcity has led to the high cost of raising rabbits. Thus, it has become imperative to source for unconventional, locally available and perhaps cheaper alternative feedstuffs compared to maize. 
Cassava root meal is an energy source with a high caloric value yield per unit area. The agronomic potentials of cassava revealed that the root meal is a suitable substitute for the reduction of maize requirements in livestock feeding (Agugu and Okeke, 2004). A range of 8$60 \%$ of cassava root meal has been recommended for inclusion in livestock feeds (Igwebuike and Okonkwo, 1993; Esonu and Udedibie, 1993; Agugu and Okeke, 2005).

The study was therefore designed to investigate the replacement value of unpeeled cassava root meal (UCRM) for maize in the diets of weaned rabbits.

\section{Materials and Methods}

\section{Location}

The feeding trial was conducted at the Livestock Teaching and Research Farm of Ambrose Alli University, Ekpoma, Nigeria.

\section{Sources of ingredients}

Unpeeled cassava root tubers were purchased from the open market in Ekpoma, Edo State. Other feed ingredients were sourced from Benin City.

\section{Processing of cassava root tubers}

The unpeeled cassava root tubers were washed thoroughly with water, chopped into small pieces and sun-dried on a concrete floor for about 4-5 days at an atmospheric temperature. The dried cassava chips was then milled into flour to form the unpeeled cassava root meal (UCRM). The meal contained $10 \%$ moisture

\section{Experimental diets}

Four experimental diets were formulated such that diet 1 contained $0 \%$ unpeeled cassava root meal (UCRM) and 45\% maize. Diets 2, 3 and 4 were constituted by replacing maize in diet 1 with 10 , 20 and $30 \%$ UCRM (Table 1).

\section{Experimental rabbits and design}

A total of twenty four six-week old weaned rabbits of mixed breed (New Zealand $x$ Chinchilla) with average initial weight of $560 \mathrm{~g}$ were used for the eight week feeding trial. The animals were randomly selected and assigned to each diet on weight equalization basis in a complete randomized design (CRD). Each group was further subdivided into replicates of 3 rabbits each and each replicate was kept in a three tier rabbit hutch of $45 \mathrm{~cm} \times 30 \mathrm{~cm} \times 42 \mathrm{~cm}$. The rabbits were weighed at the beginning of the experiment and they were supplied feed and water ad libitum. Thereafter, weekly feed consumption and weight changes were recorded. The experiment was terminated when the rabbits were twelve weeks of age and records of weekly feed consumption and weight changes were used to calculate weight gain, feed conversion ratio and protein efficiency ratio for eight weeks. Feed conversion ratio was obtained by the feed : gain ratio, while protein efficiency ratio ( PER ) was calculated using the formula below:

Weight gain/ week $(\mathrm{kg})$

Protein efficiency ratio $=$

Protein intake/ week $(\mathrm{kg})$

At the end of the feeding trial, one rabbit was selected from each replicate and weighed. Each rabbit was then starved for 12 hours, slaughtered, eviscerated and cut into parts. The lumbar region and hind limbs muscles meat were selected and cooked on a Bunsen burner for 20 minutes at temperature of $105^{\circ} \mathrm{C}$. The cooked meat was then removed from the burner and allowed to cool for 10 minutes before they were deboned. The cooked pieces of muscles meat were served to twenty- membered taste panel drawn within the university community using the 9 - point Hedonic scale (Lammond, 1982). At successive intervals of chewing, each panelist was served with 
Table 1 Percentage composition of experimental diets

\begin{tabular}{|c|c|c|c|c|}
\hline \multirow{3}{*}{ Ingredients } & \multicolumn{4}{|c|}{ Replacement levels of UCRM(\%) } \\
\hline & 0 & 10 & 20 & 30 \\
\hline & & & & \\
\hline$\overline{\text { Maize }}$ & 45.00 & 35.00 & 25.00 & 15.00 \\
\hline Unpeeled cassava root meal & 0.00 & 10.00 & 20.00 & 30.00 \\
\hline Soyabean meal & 20.00 & 20.00 & 20.00 & 20.00 \\
\hline Fishmeal & 1.00 & 1.00 & 1.00 & 1.00 \\
\hline Palm Kernel fibre & 13.50 & 13.50 & 13.50 & 13.50 \\
\hline Wheat offal & 16.00 & 15.00 & 14.50 & 13.50 \\
\hline Palm oil & 0.00 & 1.00 & 1.50 & 2.50 \\
\hline Oyster shell & 1.50 & 1.50 & 1.50 & 1.50 \\
\hline Bone meal & 2.50 & 2.50 & 2.50 & 2.50 \\
\hline Premix (Min\&Vit) & 0.25 & 0.25 & 0.25 & 0.25 \\
\hline Salt & 0.25 & 0.25 & 0.25 & 0.25 \\
\hline Total & 100.00 & 100.00 & 100.00 & 100.00 \\
\hline Calculated Analysis & & & & \\
\hline Metabolizable energy $(\mathrm{kcal} / \mathrm{g})$ & 2.18 & 2.56 & 2.54 & 2.52 \\
\hline Crude protein $(\%)$ & 18.00 & 18.00 & 17.98 & 17.98 \\
\hline Crude fibre $(\%)$ & 10.00 & 10.30 & 10.50 & 10.90 \\
\hline
\end{tabular}

Premix contaned: Vitamin A 1500 i.u; vitamin D 3000 i.u; vitamin E 12 i.u; vitamin $\mathrm{K} 2.4 \mathrm{mg}$; thiamine $3.0 \mathrm{mg}$; riboflavin 6.0mg; pyriodoxine $4.8 \mathrm{mg}$; nicotinic acid $43 \mathrm{mg}$; calcium panthotenic acid $12 \mathrm{mg}$; biotin $0.6 \mathrm{mg}$; vitamin $\mathrm{B}_{12} 0.024 \mathrm{mg}$; vitamin $\mathrm{B}_{2}$ smg; folic acid12mg; choline350mg; manganese $56 \mathrm{mg}$; iodine $1 \mathrm{mg}$; iron $20 \mathrm{mg}$; copper $10 \mathrm{mg}$; zinc $50 \mathrm{mg}$; cobalt $1.25 \mathrm{mg}$

crackers biscuit and drinking water to reduce the carry over effect of the taste of the previous sample. The panelist scored for appearance, taste, texture, chewness, aroma and overall acceptability.

The cost per $\mathrm{kg}$ feed, cost of feed consumed and cost of feed per $\mathrm{kg}$ weight gain were used to estimated the economics of production.

\section{Statistical Analysis}

Data generated were subjected to a one- way analysis of variance (ANOVA) and treatment means were compared using the Duncan's multiple range test (Steel and Torrie, 1990) with the aid of SAS (1997).

\section{Results and Discussion}

The effect of the test diets on weight gain, feed conversion ratio and protein efficiency ratio Table 2) revealed that only the average weight gain was significantly $(\mathrm{P}<0.05)$ affected. The total and daily weight gains increased progressively as the level of inclusion of UCRM increased level from $0-30 \%(754 \mathrm{~g}-799 \mathrm{~g})$ and $(45.96 \mathrm{~g}-48.49 \mathrm{~g})$ respectively. There was a slight decrease in the feed intake of rabbits due to the inclusion of UCRM, but this was not significant $(P>0.05)$. The lowest total and daily feed intake values were obtained in $10 \%$ UCRM based diet $(3.02 \mathrm{~kg}$ and $53.99 \mathrm{~g}$ ), followed by $3.03 \mathrm{~kg}$ and $54.16 \mathrm{~g}, 3.04 \mathrm{~kg}$ and $54.36 \mathrm{~g}, 3.07 \mathrm{~kg}$ and $54.75 \mathrm{~g}$ in 20,30 and $0 \%$ UCRM based diets respectively. This could be due to the low palatability of the diets and this agrees with report of Muller et al (1974) that cassava rootmeal is low in palatability and increasing the levels in the diets subsequently reduces the palatability of such diet. Feed conversion and protein efficiency ratios were not significant $(\mathrm{P}>0.05)$ influenced by the dietary treatments. However, the improvement in the liveweight and weight gain of rabbits with 
Table 2 Performance characteristics of rabbits as influenced by the dietary treatments.

\begin{tabular}{|c|c|c|c|c|c|}
\hline & \multicolumn{5}{|c|}{ (Replacement levels of UCRM (\%)) } \\
\hline & 0 & 10 & 20 & 30 & \\
\hline \multicolumn{6}{|l|}{ Parameters } \\
\hline Initial Iveweight (g) & 560 & 560 & 560 & $560-$ & \\
\hline Average liveweight $(\mathrm{kg})$ & $1.29^{\mathrm{b}}$ & $1.35^{\mathrm{a}}$ & $1.35^{a}$ & $1.36^{\mathrm{a}}$ & 0.04 \\
\hline Total weight gain (g) & $754^{\mathrm{c}}$ & $772^{b}$ & $782^{\mathrm{b}}$ & $799^{a}$ & 0.02 \\
\hline Daily weight gain (g) & $45.96^{\mathrm{c}}$ & $47.92^{b}$ & $48.46^{\mathrm{a}}$ & $48.49^{\mathrm{a}}$ & 0.42 \\
\hline Total feed intake $(\mathrm{kg})$ & 3.07 & 3.02 & 3.03 & 3.04 & 9.92 \\
\hline Daily feed intake $(\mathrm{g})$ & 54.75 & 53.99 & 54.16 & 54.36 & 0.24 \\
\hline Feed conversion ratio & 1.92 & 2.00 & 1.94 & 1.94 & 0.02 \\
\hline Protein efficiency ratio & 1.52 & 1.50 & 1.56 & 1.56 & 0.02 \\
\hline Cost per kg feed $(\mathrm{A})$ & 54.28 & 50.51 & 47.66 & 44.86 & - \\
\hline Feed cost $/ \mathrm{kg}$ weight gain & 28.28 & 25.21 & 24.64 & 22.75 & - \\
\hline Cost of production (A) & 783.28 & $779.5 \mathrm{I}$ & 776.69 & 773.86 & - \\
\hline Mortality (\%) & 0.00 & 0.00 & 0.00 & 0.00 & \\
\hline 0.00 & & & & & \\
\hline
\end{tabular}

abc: Means in the same row with varying superscripts differ significantly $(P<0.05)$

Table 3: Organoleptic Properties of rabbit meat as affected by the dietary treatments

\begin{tabular}{lccccc}
\hline \multicolumn{7}{c}{ Replacement levels of UCRM (\%) } & & & \\
& 0 & 10 & 20 & 30 & SEM \\
Parameters & & & & & \\
\hline Appearance (\%) & 4.18 & 3.99 & 30.9 & 3.91 & 0.19 \\
Taste (\%) & 3.91 & 3.55 & 3.73 & 3.36 & 0.22 \\
Juiciness (\%) & 4.09 & 4.00 & 3.73 & 4.09 & 0.21 \\
Texture (\%) & 4.09 & 3.73 & 4.00 & 4.00 & 0.21 \\
Chewness (\%) & 3.99 & 4.09 & 3.82 & 4.18 & 0.16 \\
Aroma (\%) & 4.09 & 3.82 & 3.45 & 3.82 & 0.20 \\
Overall acceptability & 4.27 & 3.82 & 3.45 & 3.82 & 0.18 \\
\hline
\end{tabular}

corresponding increase in the inclusion levels of UCRM for maize may be ascribed to adequate supply of nutrients from URCM which lend support from the report of Bamgbose et al (1997) that lack of adequate nutrients particularly dietary fibre can lead to reduced growth rate.

The similarity in feed intake, feed conversion ratio and protein efficiency ratio of rabbits in all the dietary treatments in this study indicate that the quality of protein in UCRM is not inferior to that of maize (Ikurior and Achadu 1995, Agunbede et al 2001; Tuleum et al 2005). This supports the findings of Esonu and Udedibie (1993) who fed weaned rabbits with cassava peel meal and found no significant variation in the feed conversion ratio and protein efficiency ratio.

Table 3 shows the effect of the dietary treatments on the organoleptic properties of rabbit meat. The inclusion levels of UCRM had no significant $(P>0.05)$ effect on the appearance, taste, juiciness, texture, chewness, aroma, and overall acceptability of boiled rabbit meat. This can be explained by the observation of Briedenstein and 
Carpenter (1983) that colour, flavour, juiciness and tenderness are the primary determinants of the eating quality of meat. The non significant effect of the test diets on these qualities may be related to the non hazardous effect of the antiquality (HCN) of UCRM which was eliminated by the processing procedure adopted.

The cost of various feed ingredients at the time of the feeding trial put the cost per $\mathrm{kg}$ feed, feed cost per kg weight gain and production cost at N54.28 - N44.86, N28.24 - N22.25 and N783.28 $\mathrm{N} 773.26$ in diet 1 to diet 4 respectively. These values decreased progressively with increase in the inclusion levels of UCRM. In rabbits on the lowest inclusion level (10\%) of UCRM, the cost of producing a kilogram of rabbit was N3.07 cheaper than the control diet ( $0 \%$ UCRM), let alone those on $30 \%$ UCRM inclusion with $\mathrm{N} 5.53$. The reduction in the feed cost obtained in this study agrees with the report of Tewe (1995). In a large scale rabbit production however, a reduction in the feed cost of producing a kilogram of rabbit is of valuable economic importance.

\section{Conclusion}

The overall results of this trial indicated that UCRM can constitute up to $30 \%$ of maize in rabbit diets with guaranteed performance, overall acceptability of rabbit meat and reduction in feed cost. Therefore, the utilisation of UCRM as replacement for maize in commercial rabbit enterprise in Nigeria is strongly recommended with a view to reducing the current demand pressure on maize and the cost of raising rabbits.

\section{References}

Aduku A.O. and Olokosi J.O 1990. Rabbit Management in the tropics-Production, Processing, utilization, marketing, economies, practical, training, research and future. Living Rooks Publishers, Abuja pp 43-56.

Agugu G.O. and Okeke G.C. 2005. The effect of replacing maize with cassava rootmeal in the diets of pullet chicks. Proc. of the $30^{\text {th }}$ Ann. Conf. of the Nig. Soc. for Anim. Prod. (NwiP) Vol. 30 pp235 -237.

Agubiade, J.A; Adeyemi A.O; Fasina, O. F and Bagbe, S.A. 2001. Fortification of $c$ a $s \mathrm{~s}$ a $v$ a peel meals in balanced diets for rabbits. Nig. J. Anim. Prod. 28 (2) 167-173.

Bamgbose, A.M; Nwokoro, S.O; Kudi, A.C; Bogoro, S; Egbo, M.L; Kushwaha, S. 1997. Effect of feeding tigernut ( Cyperus rotundus) meal in the performance of rabbits. Trop. Anim. Hlth. Prod. 29: 60 - 62.

Biobaku, W.O. 1998. Growth response of rabbits fed graded levels of groundnut shell, effect on organ weights and enzyme activities. J. Pure and Appl. Sci 1(1): 44-50.

Biobaku, W.O; Bamgbose, A.M. and Achike, C.U. 2003. Utilization of different p r o t e i n sources for growing rabbits. Pertanika J. Trop. Agric. Sci. 26(2): 73-77.

Briedenstein, B.C. and Carpenter, Z.L. 1983. Nutrient value of meat. J. Anim. Sci. 57:119.

Esonu, B.O. and Udedibie A.B.I. 1993. The effect of replacing maize with cassava peel meal on the performance of weaned rabbits. Nig. $J$. Anim. Prod. 20: (1\&2): $81-85$

Igwebuike, J.U. and Okonkwo, A.C. 1993. Cassava (Manihot esculenta) as an alternative energy for poultry: A review. Proc. $18^{\text {th }}$ Conf. Nig. Soc. Anim. Prod. 21 $-25^{\text {th }}$ March Federal University of technology, Owerri pp 47. 
Ikurior, S.A. and Achadu, G.A. 1995. Replacement of maize with cassava root meal alone or mixed with brewers yeast slurry in diets for growing finishing pigs Nig. J. Anim. Prod. 22 (2): 58-153.

Lammond, E. 1982. Methods of sensory evaluation of food. Canada Dept. of Agric.

Muller, Z; Chou, K. C and Nah, K. C. 1974. Cassava as a total substitute for cereals in livestock and poultry rations. World Anim. Rev. 12(1): $19-24$

S.A.S - Statistical Analysis System. 1997. SAS Users guide statistics (Cary- NC S A S Institute)

Steel, R.G. and Torrie, J. H. 1990. Principles and procedures of statistics. $A$ biometrical approach McGraw Hill BooK Co. New York, USA.
Tewe, O.O. 1995. Feeding ingredient and ration formulation for economic gains. Proc. of $1^{\text {st }}$ August School, Department of Animal Science, University of Ibadan, Ibadan

Tuleum, C.D; Njike, M.C; Ikurior, S.A. and Ehiobu, N.G. 2005. Replacement of maize with cassava root meal/brewers yeast slurry in the diets of broiler chicks. Proc. $30^{\text {th }}$ Conf. Nig. Soc. Anim. Prod. 20 ${ }^{\text {th }}-24^{\text {th }}$. March 2005 University of Nigeria, Nsukka pp 183-185

(Received 16 $6^{\text {th }}$ Sept. 2005; Accepted $5^{\text {th }}$ February, 2007). 